\title{
Banking on the Brink: The Sub-Prime Mortgage Crisis and R. K. Narayan's Novel The Financial Expert
}

\author{
Negocios bancarios en el límite: la crisis de las hipotecas \\ basura y la novela de R. K. Narayan, The Financial Expert
}

ABSTRACT: According to Umberto Eco, «every story tells a story that has already been told» (Eco, 1985: 19). In this context, The Financial Expert, a novel written by R. K. Narayan in 1952 shares interesting analogies with significant events and persons in the postmodern world of finance during the last twenty years or so. Narayan's understanding of the world of finance echoes recent phenomena like the bankruptcy of the Lehman Brothers on 15 September 2008, the Ponzi scheme of Bernard Madoff, a swindler during the 1990s, the Sub-prime Mortgage Crisis, etc. This paper traces analogies among them and thus opens up a fascinating world of intersections and cross-references. In this intricate world, the present and the past, the real and the fictional, the existing and the evolving - all interact with each other; and the pathways thus created invite our attention to the recurring economic phenomenon of bubble formation and its eventual burst. This paper rests on the premise that the exploration of the deeply-rooted analogical relationship between various texts can make the understanding of the world of finance more comprehensible.

Keywords: intertext, bubble, shadow banking, Ponzi scheme, moral hazard, securitization, greed.

Resumen: Según Umberto Eco (1985: 19), «todas las historias cuentan una historia que ya ha sido contada». The Financial Expert, escrita en 1952 por R. K. Narayan, presenta interesantes analogías con acontecimientos y personas significativas en el mundo financiero posmoderno de los últimos veinte años. El conocimiento del mundo financiero por parte de Narayan resuena con los recien- 
tes fenómenos de la bancarrota de Lehman Brothers el 15 de septiembre de 2008, el esquema Ponzi del estafador durante los años 1990, Bernard Madoff, la crisis de las hipotecas basura, etc. Este artículo explora las analogías entre tales hechos para descubrir un fascinante mundo de intersecciones y referencias cruzadas. En ese complejo mundo, el presente y el pasado, lo real y lo ficticio, lo existente y lo emergente, interactúan, invitándonos a reflexionar sobre el fenómeno recurrente de la formación y estallido de las burbujas financieras. El análisis de la profunda relación entre textos diferentes puede ayudar en la comprensión del mundo financiero.

Palabras clave: intertexto, burbuja financiera, banca en la sombra, esquema Ponzi, riesgo moral, titulización, avaricia.

The act of reading, theorists claim, plunges us into a network of textual relations. To interpret a text, to discover its meaning, or meanings, is to trace those relations. Reading thus becomes a process of moving between texts. Meaning becomes something which exists between a text and all other texts to which it refers and relates, moving out from the independent text into a network of textual relations. The text becomes the intertext. (Allen, 2007: 1)

This paper focuses on the complex mechanism the banking business usually thrives on by analyzing R. K. Narayan's novel The Financial Expert (1952) as an intertext in dialogue with certain real-life phenomena and crises, like Bernard Madoff's Ponzi scheme, the Sub-prime Mortgage crisis, the bankruptcy of global banks like the Lehman Brothers, and the global economic crisis. It rests on the premise that textual rendition of these real-life events in media and popular imagination reads dialogically with Narayan's novel, and opens up an interesting discourse on the business of banking that is prone to go awry any time owing to human greed for wealth. The bankruptcy of the Lehman Brothers Holdings Inc., the insolvency of Margayya, the protagonist in the novel, and the Ponzi scheme of Bernard Madoff read like curious case histories and lay bare the sensational nature of the banking business when it becomes adventurous. How these micro-failures pave the way for macro- 
failures in the form of massive crises like the recent ones can be understood more clearly by having a look at the way certain individuals and institutions become adventurous beyond their capacities and wreak havoc for millions in the wake of their downfall.

The Financial Expert, written in 1952 by R. K. Narayan, narrates the financial career of Margayya, a money-minded middle-aged private banker in Malgudi during the 1940s. Written at the time when most countries in the postwar period adopted Keynes' ideas on economic policy, the novel presents a fictional account of money lending and private banking in India at that time. The decade of the 1940s in India was one of the most tumultuous times in her history: fighting its last battle to get freedom from the British, India was an unwilling participant in World War II; its economy was largely market-driven in spite of the late realization by her British masters of the need for state intervention. Actually, the British policy of economic liberalism and a selfregulating market had left people especially from the rural areas at the mercy of mahajans (traditional moneylenders in India). These moneylenders were free to charge exorbitant rates of interest to their clients in the form of cash or kind. It gradually resulted in widespread rural indebtedness and land alienation. The late interference of the colonial masters with the financial market in the form of the Co-operative Movement to contain rural poverty and indebtedness lies in the background of the novel. William Walsh (1983: 72) rightly avers that The Financial Expert is «an exact account of village usury and city deceit and a controlled probing into the motives of money-making».

Margayya, a reputed financer of Malgudi passes through many stages of mercurial rise in his financial career before he eventually meets his furious fall owing chiefly to his penchant for adventurous banking. The novelist divides the tale of his financial wizardry into three distinct phases which can be equated with Paul Krugman's analysis of the history of banking business in the Us. Krugman divides the financial history of the us into the following three eras: (i) before 1930 when banking was an exciting industry featuring a number of larger-than-life figures who built giant financial empires, some of which were based on fraud; (ii) the post-Depression phase between 1930 and 1980 when banking became boring due to tight state regulations; and (iii) the post1980 phase when banking became exciting again after most of the regulations were lifted and finance again became a high-paying career (Krugman, 2009 b). This description of the national history of banking business in the us finds its interesting parallel in the personal history of Margayya in the novel as far as the level of adventure involved is concerned: the first phase depicts Margayya as a commission agent sitting under a banyan tree before the Central Co- 
operative Land Mortgage Bank in Malgudi, and managing the nitty-gritty of land mortgages for the illiterate peasant-clients of the bank. This business is quite close to his heart as it is full of adventure. He remains at the centre of all the complex transactions of the bank by clearing up the «red-tape» hurdles from the path of customers seeking loans from the bank (Narayan, 2007: 3). His clients hail him as «a wizard» who employs his «contrivance» to enable them «to draw unlimited loans from the Co-operative Bank» (Narayan, 2007: 2). This adventurous phase in Margayya's financial career comes to an abrupt end when the Secretary dismisses him from the courtyard of the Bank and the same day his only son Balu tears off his accounts book at home and throws it in the gutter. After a forty-day propitiation of Lakshmi, the Hindu goddess of wealth, Margayya begins a career as printer and becomes very rich and reputed very soon. However, he finds this printing business too «boring» and «alien» for a «genius» like him (Narayan, 2007: 117). He actually craves for «an adult business» with «sufficient adventure in it» (Narayan, 2007: 118). He subsequently sells his share in the printing business to his partner in order to become a banker in his own right. This brings the second phase of his career to a close. In the third and final phase, he becomes a banker, acquires an office in the Market Road, the busiest street in Malgudi, and starts dealing in the mysteries of money. The whole day now he has «to talk, counsel, wheedle out, and collect money; in fact go through all the adventures of money-making» (Narayan, 2007: 148). That leaves him extremely tired at the end of the day. Still he enjoys his banking business too much. Very soon he «earns» his place «among the elect in society»: people flock to him «for guidance, advice and management» (Narayan, 2007: 124). His reputation as a «Wizard» (this time with capital 'W') among his clients returns. His clients now include the «wellto-do people» as well as «smaller tradesmen and clerks and workers» of the region (Narayan, 2007: 200). Whatever he now says sounds «authoritative and mature»; people listen to him «with respectful attention» (Narayan, 2007: 149). This enviable description of Margayya sitting in his office with his clients surrounding him resonates well with the manner global experts in wealth management appear regularly in the media nowadays to guide people in money matters. Certain institutions even think of conferring on him «a title» for «doing the greatest public service» by making people «happy and secure» through his «help»; the narrator reports that even the Government thinks of giving him «at least a Public Service Medal» for his social services (Narayan, 2007: 200). But one day Margayya's financial house of cards crumbles down to dust within moments when Dr. Pal, his most trusted agent, begins spreading rumour about the former's mental health. As the rumour spreads in the market 
like a wild fire, people begin to throng Margayya's house demanding their deposits back there and then. By afternoon that day «all the cash in the house was gone» and still there «seemed to be only one theme for all the cries: "My money! My money gone! All my savings gone!"» (Narayan, 2007: 215-16). Ultimately, Margayya has to file for insolvency to save himself and his family from the fury of his clients.

When Graham Greene (1966: viii) describes the novel as a satire on «modern desire for wealth», he brings under scrutiny the human weakness for money much aggravated by laissez faire policy and capitalist economy. The novel reads like an intertext inspiring a series of analogies among various texts which resonate and reverberate in one another. The events and institutions of particular interest in the present context are the Ponzi scheme of Bernard Madoff during the 1990s and the bankruptcy of the Lehman Brothers driven by the sub-prime crisis in 2008. Interestingly, Madoff and the Lehman are also the sweet but poisonous fruits of adventurous banking, as Margayya is in the novel. The Lehman Brothers, for instance, began as a modest dry-goods store in 1850 and gradually expanded its business in diverse areas before setting its eyes on the business of asset-management during 1990s. The coming times witnessed a dazzling expansion in its assets and workforce. During these times, it emerged as an iconic figure for bankers. Before going bankrupt on 15 September 2008, it had amassed assets worth more than $\$ 275$ billion under its management. This amount was remarkable in the sense that it was $600 \%$ more than its assets just fourteen years before in 1994. In the words of Frei, «Lehman's bosses, led by Richard Fuld, peddled billions of dollars worth of bundled sub-prime mortgages every month and made a mint from fees and commissions» (Frei, 2009). Awed by its spectacular «success» in the world of finance, the organizers of the 2008 ALB China Law Awards hailed it with such glorious titles as 'Debt Market Deal of the Year' and 'Equity Market Deal of the Year'. Ironically the same year this «too-big-to-fail» institution suffered heavy losses in the share market due to the bursting of «the sub-prime mortgage bubble which it helped to inflate» (Frei, 2009). After that, its impressive goodwill in the market kept on downsliding bearishly. When it realized that the losses it had accrued were beyond recovery, it filed for insolvency and sought bankruptcy protection on 15 September 2008. The next morning witnessed unprecedented scenes of Lehman employees removing files and other items with the company logo from its famous World Headquarters in New York. That day the Lehman shares tumbled over $90 \%$ in the share market. On September 17, 2008, the New York Stock Exchange delisted it from its exclusive list of trading companies, thus sealing the fate of this iconic investment bank. Preceding that, however, the Lehman had already set 
the stage for many more such failures in the coming days resulting into severe damages to the world economy that it still has to recover from.

Like the Lehman, Bernard Madoff, a swindler, who was later sentenced to imprisonment for 150 years by the Manhattan Court, also «had earned a reputation as a trusted money manager with a Midas touch» during the 1990s. Even as the market fluctuated, the clients of his famous «Ponzi scheme» (also called «Pyramid Scheme») garnered steady double-digit returns for decades («Madoff gets 150 years», 2009). But his Ponzi scheme worth $\$ 65$ billion was essentially a fraud devised to lynch financially his unsuspecting investors. In reality he, like Margayya, never made any investments. He rather used the money from new investors to pay returns to the existing clients and to finance a lavish life-style for his family. The money-spinning frauds like Madoff who have seldom been out of market lie behind Margayya as his real-life prototypes. The novelist himself admits that Margayya is «a combination of two personalities»: one was «a gentleman in Mysore who encouraged people to borrow and spend, shattering once and for all the philosophy of thrift», and the other one was a fraud in the region who "promised dazzling, fantastic scales of interest and dividends on the money entrusted to his care, and he became the only subject of conversation until he crashed and landed in jail» (Narayan quoted in Prasad, 2013: 321). The echoes of the accounts of real-life frauds in the novel betray how the literary text can be intertwined with numerous fibers of other texts, opening it up to networks of meanings.

Within the corpus of Narayan's writings too Margayya is not an isolated case signifying a lethal lure for wealth. He actually vies with some of Narayan's other persona from Malgudi fiction, especially Sampath from Mr. Sampath (1949) and Raju from The Guide (1958), in his mammoth greed, overambitious cunning and eventual downfall. Narayan's moral outlook gets these Malgudians invariably into trouble by introducing his ethics into his narratives. His typically Indian theological belief that lures of money are always deceptive and hence dangerous comes to the fore when he makes Margayya realize: «But money is not everything» (Narayan, 2007: 95). The same Margayya has earlier averred: «Money was man's greatest need, like air and water» (Narayan, 2007: 22). Money actually fails to give these characters the exact happiness that comes only from satisfaction in life; and every traditional Indian is trained to dream to have this kind of satisfaction in life. Nonetheless, this realization is momentary in the life of Margayya, a typical Hobbesian man, who remains selfish, greedy and cunning throughout the novel in order to spin more and more money. 
The novel refers to the exploitation of the gullible rural folks, aggravated by the inscrutable ways of moneylenders, and the illiteracy and conservatism of the common people. In this context, the scene from the Bollywood movie Mother India (1960), wherein Birju the protagonist asks for the accounts book when the moneylender comes with his goons to take away his harvest, comes aptly to mind. The moneylender readily puts the book before him. But Birju and, for that matter, everyone in his community fails to decipher the moneylender's privileged knowledge. Margayya's doings seem as inscrutable as the former for his clients. The novel is deeply rooted into the contemporary social, economic, political and cultural reality of India, reflected through the fictional town of Malgudi. This socio-cultural milieu is further enriched through references to the dowry system, drinking, gambling, red-tapism and corruption - the banes of Indian society. In such a society to find money-mongers like Margayya is not a difficult task at all. However, looked at from the perspective of an unprivileged common man, the 1940s and the 2000s are not so different from each other in essence. The ways of private banking still remain inscrutable to laymen in spite of the spread of education. The people of the 1940s in the novel fall victim to moneylenders like Margayya only in dire circumstances, whereas the number of the victims of the Lehman and Madoff stands multiplied in present times owing primarily to the culture of consumerism. In the absence of any moral regulation in the postmodern world human greed for money has also multiplied geometrically. During the 1940s and 1950s India needed to balance her economy for the welfare of the poor millions. In the twenty-first century India and many other countries also need to reorient their state policies to save the poor from the onslaughts of globalized markets. In such a scenario Narayan's novel becomes more contemporary and relevant, fitting into the role of an intertext for the discourse of private banking.

Analogical links between the fictional and actual financial frauds provide eye-opening illustrations of the adventurous banking practices followed by most of the bankers, especially when the regulating agencies are found wanting. These traces also throw a revealing light into the murky realities of the business world, which always keeps the economy vulnerable to frauds and scandals. The recent global financial crisis along with the fictional downfall of Margayya also exposes the inherent weaknesses of any capitalist financial system that leaves the economy at the mercy of the market forces. The market forces, driven blindly by the sole purpose of maximizing their profit, pave the way for bubbles. Institutions like the Lehman Brothers, and individuals like Margayya and Madoff succeed in inflating the bubble every time because they work in tandem to cash in on the human madness for money. They prove time and again 
that maximum people can be fooled for a much longer time by keeping them allured by promises of hot returns and not letting them have a chance to peep into their actual dealings. ${ }^{1}$

The factors - economic as well as human - that lie behind these kinds of financial frauds, whether at the individual or the institutional levels, are more or less the same. The most obvious economic reason to cause the recent subprime mortgage crisis was the indulgence of the multinational iconic banks like the Lehman Brothers, Bear Stearns, Merrill Lynch, Morgan Stanley, Goldman Sachs, etc., into financial engineering. Prompted to perform better in the form of higher returns in the short term, these banks introduced a computerized system of financing in the form of securitization. Krugman rightly asserts in this regard:

Underlying the glamorous new world of finance was the process of securitization. Loans no longer stayed with the lender. Instead, they were sold on to others, who sliced, diced and pureed individual debts to synthesize new assets. Subprime mortgages, credit card debts, car loans - all went into the financial system's juicer. (Krugman, 2009 a)

The computerized system of securitization was too complex for the human mind to comprehend; but it was allowed to go on as it proved to be extremely rewarding for the bankers. Extremely lax government policies and an unusually long span of boom in the realty sector made the operations of securitization affordable for the time being.

Even the seasoned players of the financial world felt tempted to believe, like Keatsean honeybees, that «the warm days will never cease» (Keats, 1993: 363). However, once the market conditions became less favourable, the risks hidden behind the system of securitization began to surface. Very soon there emerged the unenviable situation of systemic risk. By then it became obvious that the system of securitization had actually encouraged a shadow banking system and moral hazard. But it was too late to do anything to contain the damage by streamlining the system due to the elaborate interconnections among the national economies across the globe. These economic factors are merely the visible symptoms of a much serious problem whose roots lie in certain human and cultural factors. Such factors have augmented not only the recent global

1. Once the famous scientist Isaac Newton also became a victim of the speculative market. He invested some money in the share market for hot returns. But he lost his money in the whirl of the South Sea Bubble. After this bitter experience, he opined: «I can calculate the motions of heavenly bodies, but not the madness of people» (quoted by O'Hara, 2008: 14). 
financial crisis, but also all the other similar crises in the past. They include, among other things, human love for speculation, poor judgment, lack of trust, dominance of greed over ethics, etc. Frei (2009) rightly states: «Trust broke down between banks, as no one knew just how much money they owed». All these economic and human factors combined together to create «a disconnect from the real world» and led the seemingly robust financial system of the globalized market «to the inevitable collapse» (Rao, 2009). Narayan's novel explores these human and cultural factors in a systematic way, thus enriching its potential as an intertext.

The Financial Expert shows the phenomenon of shadow banking and bubble formation more explicitly when it is read as an intertext. It appears to be a fictional attempt to lay bare the modus operandi of the private bankers that push the whole economic system into crises now and then. Margayya, modeled after a real-life cheat, ${ }^{2}$ is the fictional representative of all the real life «financial engineers» and "experts» who play havoc with the whole system by reducing their business to the level of a gamble. Stiglitz's observation is worth mentioning here: «But much of the innovation of recent years was little more than accounting, regulatory, and tax arbitrage; it did not lead to better resource allocations or improved risk management» (Stiglitz, 2008). In fact, Narayan also describes Margayya as a «financial engineer» and «a specialist in money» (Narayan, 2007: 134). No doubt, he does not have, unlike his equivalents in the globalized world, any computer software at his disposal to formulate foolproof financial equations. He nevertheless uses his own ingenious calculations as a usurer to exploit the infinite potential money has for him. A glimpse at his ingenious financial engineering might serve as an example: whenever a customer borrows money from him, he holds the first instalment of interest on that amount at the source itself. He re-lends this amount to another customer but, again, only after having deducted the first instalment of interest on that amount at the source itself. He repeats this process till he can lend the smallest amount and, thus, makes a profit in the form of transaction fees as well as multiple interests on the same amount of money. This and many other methods employed by him are, like those of the multinational banks, «too complex for anyone to understand» (Narayan, 2007: 195). Everybody is obviously «puzzled» to see his deposits

2. Iyenger (1999: 377) refers to such another fraud in the following words: «There was, three decades ago, the original of Margayya whose rates of interest lured princes and professors, scientists and civil servants, and made fool of them all. Narayan's art lies in giving such a financier an actuality of his own by setting him in a background as fantastic as his personality and career». 
multiply overnight. People speculate how «the wizard» does it. But no one has any clue to his money mystique. Guru Raj, one of his customers, calls him «a very great thinker», «a rare man» who has «understood all these matters» related to money (Narayan, 2007: 132). What else were the multinational banks doing in the name of banking immediately before their exposure in 2008 ?

Margayya, like a shadow banker, provides banking facilities even to those customers who are not entertained by the law-regulated Co-operative Mortgage Bank for their being defaulters. When the Co-operative Bank in Malgudi «expels» Kanda of Somanur for «default» (Narayan, 2007: 153) and refuses to give him a new loan, Margayya manages a loan for him by manipulating the provision for joint-loans. He convinces Mallanna, another customer, to become a party in it. He coerces him to take a loan from the bank in his own name and re-lend it to Kanda on a higher rate of interest. It is due to this ingenuity of Margayya that customers come to him instead of going directly to the Cooperative Bank. He too loves to create these kinds of financial innovations and demonstrate his «wizardry» before his gasping customers. Later on, when the war breaks out, Margayya offers interest rates much higher than those offered by regular banks, and so attracts almost all the money of the region to his safe. In Narayan's world, the regular banks do not connive with Margayya in his adventurous banking and, hence, the aftermath of his insolvency remains confined to his clients only. Unfortunately, this did not happen in the real world of 2008. Then, almost everybody was found neck-deep in the murky dealings of shadow banking. And hence the sub-prime mortgage crisis devastated the world economy like a tsunami.

Like the much-publicized global banks of today, Margayya too views himself as «a saviour of mankind» (Narayan, 2007: 27) for his skills to resolve the financial difficulties of his customers. Very much like them, he too thinks his job «strenuous» and feels that he deserves «the difficult income» (Narayan, 2007: 08) he earns in the form of fees and commissions. He considers his enormous wealth in the form of "gold bars in the safe at home and the cash bundles and the pass-book» not heaven sent but the result of his own «application» (Narayan, 2007: 185) and his boldness to take «risk on half-secured loans» (Narayan, 2007: 186). Interestingly, Krugman reports the case of the real-life bankers who were behind the crisis in the following words: "So why did some bankers suddenly begin making vast fortunes? It was, we were told, a reward for their creativity - for financial innovation» (Krugman, 2009 c). That innovation also included the unethical practice of advancing NINJA loans. 
The ensuing economic crisis exposed their claims of hard labour for the sake of public service as a brazen lie. It became clear that their sole interest lied not in the service of mankind but in the fees and commissions generated through their financial cunning. They actually flourished by flouting the rules and ethics of the business of banking. Like any globalized bank, Margayya does not believe in advocating thrift among his customers, which was the aim of the Co-operative movement in India, as Margayya's own living depends upon people taking more and more loans. Besides, he never bothers to know what happens to all the money his customers borrow. Actually, he dislikes the clients who are sincere in paying back their loans in time. He calls such clients full of «ingratitude» (Narayan, 2007: 152). Clients like Kanda of Somanur are his favourites for they are ready to put everything they possess in his hands. How he welcomes Kanda with a demand for another loan is significant: «I am glad you have come back to me, Kanda. I will put you out of your difficulties» (Narayan, 2007: 153). It again reminds the reader of the hot and glamorous welcome one receives at the gaudy reception counters of any multinational bank nowadays. That their sparkling fronts are actually façades for their ugly rears hardly strikes the imagination of the mesmerized customer. These banks, like Margayya, lend «easily» (Narayan, 2007: 181) without making any fuss about «legalities» (Narayan, 2007: 182). But once a customer is trapped, they charge fees and commissions and interests «in so many subtle ways» that the customer is «more or less finished» (Narayan, 2007: 183). Happily, the frugal people of Malgudi, unlike most of the modern-day consumer-clients, borrow from Margayya «only under stress» (Narayan, 2007: 182) as they know that once a client is gripped in his clutches, he will not hesitate even to impose foreclosure on him/her if s/he fails to pay back the loan. Many of them borrow to meet the demands of the dowry at the time of their daughters' marriage; and a few borrow for gambling and drinking. Whenever Margayya finds his clients «crazed and unhappy» (Narayan, 2007: 183) over the orders of the courts, he never bothers about them. He rather dismisses them by saying: «It is all in the business» (Narayan, 2007: 183). He even nullifies the provisions of «debt relief laws and such things» first by making everything look «correct on paper», and then by conniving with the law-enforcing people who are usually «enthusiastic collaborators in his scheme» (Narayan, 2007: 183). Kanda's case is worth mentioning: he used to be a well-to-do farmer with twenty acres of fertile land, a house and cattle; but now, he is finished as all of his property lies tied up in mortgages - mostly through Margayya's advice and assistance. Same was the fate of the customers of the globalized banks in the USA who invested in the 
realty sector by borrowing from banks on easy instalments, leading to the subprime crisis.

Like any other money launderer, Margayya does not trust anybody, including Madan Lal, his partner, Shastri, his accountant, and Dr. Pal, the principal instrument in his mercurial rise and furious fall. His tendency to be suspicious of everything and everybody keeps him constantly on high alert, so much so that he even begins «to doubt» (Narayan, 2007: 166) the very police inspector who helps him locate his runaway son Balu. Guru Raj's offering of an office on rent without any fuss surprises him as he is «unused to such brisk and straightforward transactions» (Narayan, 2007: 131). Narayan portrays in Margayya's over-alertness a lack of trust and nervous anxiety many businessmen suffer from. Such pattern of behaviour can be observed among the real-life players in the financial market also. This lack of trust makes any system highly fragile and susceptible to breakdown at any moment. The recurring crises in the history of finance are a fact to take into account in this regard. Every time a crisis occurs and experts analyze it in retrospect, lack of trust surfaces inevitably as one of the main causes. Even an uncreditted rumour is enough to ruin the reputation of any institution or individual within moments. Margayya also falls prey to this feature. He enlists Dr. Pal's services to build up public trust in his financial wizardry and engineering. But gradually, he finds his interests clashing with those of Dr. Pal. When one night he loses his temper and beats him out of anger, the consequences wreak havoc for him. The very next morning, Dr. Pal turns out to be his nemesis as he visits a few of Margayya's clients and narrates the incident ambiguously suggesting: "Things are probably not going smoothly there» (Narayan, 2007: 214). Taking a cue from this statement, the irrational human behaviour finds another chance to perform its tricks. Without verifying the facts, people begin to flock at Margayya's door to withdraw their deposits. Margayya begins to return their money. But very soon all the cash in the house is gone and the crowd still keeps on increasing. Ultimately, he sends for the police and a lawyer in order to file for insolvency. He spends the next three or four months «attending courts, lawyers, inventories and so on and so forth» (Narayan, 2007: 217). Ultimately, everything is gone. Even the house where his pampered son Balu is living with his family is «attached» (Narayan, 2007: 217). This description of Margayya's insolvency in the novel brings to the reader's mind the images of the tumultuous scene outside the main office of the Lehman on 16 September 2008 when the officials began to vacate the building after the firm's bankruptcy.

Margayya's indulgence in speculation by attracting people with black money presents another impeccable parallel to the work-culture of most of the 
multinational companies in the global world. Margayya knows that, due to the circumstances generated by the ongoing world war, there is an overflow of «unaccounted and unaccountable» money lying «hidden in bundled-up currency notes in dark boxes» (Narayan, 2007: 193) with merchants, contractors, drug stockists, military men, go-betweens and busybodies. As he sees in it a golden opportunity to make undreamt of profit, he, like Bernard Madoff, begins to offer twenty percent interest rates, much higher than the regular banks' meager three percent. People, who are interested only in their returns, do not bother to find out how Margayya manages to pay such a high interest rates. They rush towards him with their easy as well as hard money. In this way, Margayya's indigenous Ponzi scheme skyrockets him to «the undreamt heights of financial success» (Narayan, 2007: 191). He receives thousands of rupees every day. He, however, does not have any scheme to invest this huge money into some more productive business in order to sustain its productivity. He, like any speculator, keeps it stored up in his house and relies on his fanatical calculation: «If I get twenty thousand rupees deposit each day and pay fifteen in interest, I have still five thousand a day left in my hands as my own» (Narayan, 2007: 195). Before going bankrupt, he has money hoarded in his house not only in an iron safe but also in «the cupboards, the benches and tables, the space under the cot, and the corners» (Narayan, 2007: 200). Narsimhan (2008) rightly observes in this regard: «Forgotten in the euphoria of this financial alchemy is the basic tenet that financial sector has no standing of its own. It derives its strength and resilience from the real economy». Margayya forgets it; Madoff forgot it; the Lehman Brothers and the likes also forgot it. As their financial «innovation» failed to ensure a better resource allocation or improved risk management, they, despite all their wizardry, engineering and mysticism in money-matters, fell down the very moment most people hardly expected it. Only a few wise people like Raghuram Rajan of the University of Chicago acknowledged that the bubble was already too inflated and was waiting just for an excuse to burst. Dr. Pal in the case of Margayya, and the sub-prime mortgage crisis in the Lehman one, just pressed the metaphorical «reset button» (Dewan, 2009) to let the bubble deflate.

Harold Bloom says: «A single text has only part of a meaning; it is itself a synecdoche for a larger whole including other texts» (Bloom, 1975: 106). In this context, the striking parallels discussed in the previous pages between the dealings of actual people and institutions like Bernard Madoff and the Lehman, on the one hand, and those of the fictional Margayya, on the other, open up before the reader a fascinating world of «intense intertextual references and allusions» (Allen, 2007: 201). In this intertextual world, the present and the past, the real 
and the fictional, the existing and the evolving, interact with each other, and the intertextual pathways they create invite the reader's attention to the recurring phenomenon of bubble formation and its eventual burst causing pain for millions in their wake. At the end of the novel, the reader beholds Margayya preparing to begin his business afresh from under the same banyan tree before the Co-operative Bank as at the beginning of the novel. Iyenger (1999: 377), in describing him as a «Napoleon of finance», rightly discerns this scene as an instance of Narayan's comic irony, that invests the persona of his protagonist with a Napoleon like resilience and incorrigible will to move on in spite of colossal failures. Read dialogically, this ending finds its real-life reverberations in the decisions taken by the leading national governments over the world to bail out, instead of punishing, the sick banks for their wrong-doings. In the words of Paul Krugman, the authorities seem to believe that «once investors calm down, securitization - and the business of finance - can resume where it left off a year or two ago» (Krugman, 2009 c). It actually amounts to encouraging individuals, institutions and regulating agencies to keep on playing not only with the investors' money, but also with their trust in the system. And the common man, caught in «a crisis of culture» (Johnson quoted by Dewan, 2009) will remain destined to bear the real brunt of such crises in the future too. Arindham Chaudhury accuses common people also of their willy-nilly involvement in these kinds of crises. According to him, people driven by a culture of consumerism - a culture of use and throw facilitate «the western, diehard, capitalistic, greed-driven materialism» that thrives by creating «artificial demand» and converting consumers into «material dustbins for the profits of a handful of corporations» (Chaudhury, 2009).

After having witnessed various crises during the last twenty-five years, William Walsh (1983: 72) should revise his suggestion that the subversion of «strong Victorian-British emphasis on the qualities of self-help and thrift» into «help yourself» is what constitutes «the Indian sensibility». The fact that Narayan takes up the issue of private banking and deals with it in great detail in his novel should not encourage anyone to confine the issue exclusively to the realm of the Indian ethos. The more or less similar accounts of the goings-on in the banking sector at a global level are enough to highlight the universal greed of usurers and private bankers especially when faced with the lack of uniform regulations.

\section{References}

Allen, G. (2007): Intertexuality, London, Routledge.

BLOom, H. (1975): Kabbalah and Criticism, New York, Seabury Press. 
Chaudhury, A. (2009): «How the western recession is the real beginning of great news for India!», The Hindu, 21 April. Digital edition.

Dewan, S. (2009): «Conspicuousness is out as belt-tightening trickles up», The Hindu, 11 March. Digital edition.

Eco, U. (1985): Reflections on The Name of the Rose, London, Secker and Warburg.

Frei, M. (2009): «America: a year of financial crisis», The Hindu, 12 September. Digital edition.

Greene, G. (1966): «Introduction» in Narayan, R. K. (1966): The Financial Expert, New York, The Noonday Press. vii-viii.

IYENGER, K. R. S (1999 [1962]): Indian Writing in English, New Delhi, Sterling Publishers.

Keats, J. (1993): «Ode to Autumn» in Fifteen Poets, Madras, Oxford University Press. 363.

Krugman, P. (2009 a): «The market mystique», The Hindu, 28 March. Digital edition.

- (2009 b): «Making banking boring», The Hindu, 11 April. Digital edition.

- (2009c): «Money for nothing», The Hindu, 28 April. Digital edition.

«Madoff gets 150 years» (2009), The Hindu, 30 June. Digital edition.

Narayan, R. K. (1987): The Financial Expert, Mysore, Indian Thought Publications.

- (2007): The Financial Expert, Chennai, Indian Thought Publications.

Narsimhan, C. R. L. (2008): «From U. S. sub-prime to global economic crisis», The Hindu, 15 December. Digital edition.

O'HaRA, M (2008): «Bubbles: Some Perspectives (and Loose Talk) from History», The Review of Financial Studies, 21 (1): 14. <http://rfs. oxfordjournals.org $>$, [9-7- 2010].

Prasad, D. (2013): «The Financial Expertise of Margayya and Its Consequences in R. K. Narayan's The Financial Expert», Language in India, 13(3) (March): 317-332. <www.languageinindia.com>.

RAO, S. L. (2009): "Why the bubble burst», The Hindu, 10 March. Digital edition.

STIGLiTz, J. (2008): «Crises today and the future of capitalism», The Hindu, 22 December. Digital edition.

Walsh, W. (1983): R. K. Narayan: A Critical Appreciation, New Delhi, Allied Publishers Private Limited. 